\title{
Effect of Zinc Sulphate on Yield and Yield Attributes of Green Gram (Vigna radiata)
}

\author{
Prashantkumar $^{1 *}$ and B. M. Radder ${ }^{2}$ \\ ${ }^{1}$ Department of Soil Science and Agricultural Chemistry, \\ College of Agriculture, Dharwad \\ ${ }^{2}$ University of Agricultural Sciences, Dharwad- 580 005, Karnataka, India \\ *Corresponding author
}

\begin{abstract}
A B S T R A C T
Keywords

Zinc sulphate

and

Greengram

Article Info

Accepted:

15 January 2020

Available Online:

10 February 2020

A field experiment on the Response of greengram (Vigna radiata L.) to soil and foliar application of zinc sulphate" was conducted during khari 2016 at the Indian Institute of Pulse Research, Regional Centre,UAS, Dharwad. The experiment was laid out in randomized complete block design with ten treatments including application of zinc sulphate@ $9,7.5$ and $10 \mathrm{~kg} \mathrm{ha}^{-1}$ along with zinc sulphate spray @ 0.5 and 1 per cent at 20 DAS along with RDF and replicated trice. The results revealed that soil application of zinc sulphate $7.5 \mathrm{~kg} \mathrm{ha}^{-1}+0.5$ per cent zinc sulphate spray at 20 DAS along with RDF $\left(\mathrm{T}_{6}\right)$ was found superior in enhancing the grain yield $\left(8.65 \mathrm{q} \mathrm{ha}^{-1}\right)$ and haulm yield (19.47 q ha $\mathrm{q}^{-1}$ ) of greengram. Similarly, highest uptake of nutrients (N, P, K and $\mathrm{Zn}$ ) by the crop were recorded due to the soil application of zinc sulphate $7.5 \mathrm{~kg} \mathrm{ha}^{-1}+0.5$ per cent zinc sulphate spray at 20 DAS along with RDF $\left(\mathrm{T}_{6}\right)$
\end{abstract}

\section{Introduction}

Greengram (Vigna radiata L.) is also known as Mung bean in English and Mung in Hindi. Greengram is third most important pulse crop in India and it is highly valued as green legume. It is primarily grown during rainy season almost throughout India. Mung bean is excellent quality protein, low fat and good amount of minerals and vitamins and is easily digested. Mung bean is a legume crop and fix atmospheric nitrogen though symbiotic process. It provides excellent green fodder to cattle.

Being short duration crop it fits well in multi cropping and intercropping system. It is used as green manure crop. After picking mature pod, plant may be fed to cattle or be used as green manure. Its crop to improve soil fertility and it is also used as a cover crop. With the introduction of high yielding varieties and use 
of highly concentrated micronutrient free fertilizers under intensive cropping system increases their adoption on a large area. There is continuous depletion of soil micro and secondary nutrient status. Despite increase in the NPK fertilizer consumption in the country, crop production has not increased proportionately. Nutrient imbalance is one of the major edaphic constraints limiting productivity of pulses.

Pulses are next to cereals in terms of their economic and nutritional importance as human food. Most Indians especially vegetarian take pulses as basic ingredient in their diets as pulses are important source of vegetable protein. This leads to realize the need for secondary and micronutrient and also their effect on crop yield, nutrition and health. Among various crops grown, India is the largest producer of pulses with 24 per cent share in global production out of which green gram grown in the country, contribute about 7 per cent India's production is about $14.5 \mathrm{mt}$ of pulses from an area of 23.63 mha.

Domestic requirements of pulses in 2050 would be 26.5 million tonnes (Mt), which necessitates stepping- up production by $81 \%$ i.e. $11.9 \mathrm{Mt}$ additional produce at $1.86 \%$ annual growth rate. This uphill task has to be accomplished under more severe production constraints, especially abiotic stresses, abrupt climatic changes and increasing deficiency of secondary and micronutrients in the soil (Ali and Gupta 2012). Zinc (Zn) plays an important role in crop biomass production (Kaya and Higgs, 2002). Among the micronutrients, Zinc (Zn) and manganese (Mn) can affect the susceptibility of plants to drought stress (Khan, et al., 2003). Zinc is the only metal represented in all six enzyme classes (oxidoreductases, transferases, hydrolases, lysases, isomerases, ligases). In bio-membranes $\mathrm{Zn}$ concentration is higher than other micronutrients, due to the presence of many Zn-binding sites within the biomembranes. Some amino acids, such as Histidine (His), Glutamate (Glu), Aspartate (Asp) and Cysteine (Cys), provide ligands at these adsorption sites. Zinc binding sites also occur in a wide range of other proteins, including the largest $\mathrm{Zn}$ binding protein (the $\mathrm{Zn}$ finger domain), membrane lipids and DNA/RNA molecules. In plant cells, $\mathrm{Zn}$ does not undergo valency changes and the majority of $\mathrm{Zn}$ in leaf cells is present in the forms of $\mathrm{Zn}^{2+}$ associated with low molecular weight complexes, storage metalloproteinase, free ions, and insoluble forms associated with cell walls.

\section{Materials and Methods}

A field experiment was conducted during kharif, 2016 at Indian Institute Pulse Research, Regional Centre, UAS, Dharwad to investigate the "Effect of Zinc Sulphate application on Growth, Yield and Quality Parameters of Greengram in a Vertisol". With the treatment comprising of three levels of soil $2.5 \mathrm{~kg}, 5 \mathrm{~kg}$ and $7.5 \mathrm{~kg}$ per ha and three levels of zinc sulphate foliar application of 0.5 per cent, 1 per cent and 1.5 per cent at 20 DAS.

The experiment was laid out in randomized complete block design with three replications. The mean monthly maximum $\left(29.2^{0} \mathrm{C}\right)$ and minimum temperature $\left(21.6^{0} \mathrm{C}\right)$ were recorded in the June 2016 and August 2016, respectively during crop season. The soil was loamy sand and low in organic matter. The soil $\mathrm{pH}$ was 7.97. It was medium in organic carbon $(0.73 \%)$, available nitrogen $(338 \mathrm{~kg}$ $\left.\mathrm{ha}^{-1}\right)$ and available phosphorus (34 $\mathrm{kg} \mathrm{ha}^{-1}$ ) and medium in potassium (446 $\mathrm{kg} \mathrm{ha}^{-1}$ ) available sulphur (14 $\left.\mathrm{ka} \mathrm{ha}^{-1}\right)$ and DTPA extractable zinc was $\left(0.57 \mathrm{mg} \mathrm{kg}^{-1}\right)$. Green gram variety IIPM -2-14 (Shreya) was sown at $15 \mathrm{~kg} \mathrm{ha}^{-1}$ in line spaced at $30 \mathrm{~cm}$ at a depth of $5 \mathrm{~cm}$ by "Kera" method in open furrow. 
Table.1 Effect of Zinc Sulphate application on yield and yield attributes of greengram

\begin{tabular}{|c|c|c|c|c|c|c|c|c|}
\hline Treatments & $\begin{array}{c}\text { Plant } \\
\text { height } \\
\text { (cm) }\end{array}$ & $\begin{array}{l}\text { Number of } \\
\text { Branches } \\
\text { per plant }\end{array}$ & $\begin{array}{c}\text { Dry } \\
\text { matter } \\
\text { per } \\
\text { plant } \\
\text { (gm) }\end{array}$ & $\begin{array}{l}\text { Grain } \\
\text { weight } \\
\text { per } \\
\text { plant } \\
\text { (gm) }\end{array}$ & $\begin{array}{c}1000 \\
\text { seed } \\
\text { weight } \\
(\mathrm{gm})\end{array}$ & $\begin{array}{c}\text { Straw } \\
\text { yield } \\
(\mathbf{q} / \mathbf{h a})\end{array}$ & $\begin{array}{l}\text { Pods per } \\
\text { plant }\end{array}$ & $\begin{array}{c}\text { Seed } \\
\text { yield } \\
\text { (q/ha) }\end{array}$ \\
\hline$T_{1}:$ Control (RPP) & 23.7 & 5.6 & 13.7 & 8.1 & 27.7 & 13.97 & 22.1 & 6.57 \\
\hline $\begin{array}{l}\mathrm{T}_{2}: 5 \mathrm{~kg} \mathrm{ha}^{-1} \mathrm{ZnSO}_{4} \\
\quad \text { cured with FYM * }\end{array}$ & 27.5 & 6.3 & 15.6 & 8.9 & 31.6 & 14.54 & 24.0 & 6.88 \\
\hline $\begin{array}{l}\mathrm{T}_{3}: \mathrm{T}_{2}+0.5 \% \mathrm{ZnSO}_{4} \\
\quad \text { foliar spray }(20 \mathrm{DAS})\end{array}$ & 31.0 & 6.5 & 18.1 & 9.2 & 32.1 & 14.67 & 24.2 & 7.24 \\
\hline $\begin{array}{c}\mathrm{T}_{4}: \mathrm{T}_{2}+1 \% \mathrm{ZnSO}_{4} \text { foliar } \\
\text { spray }(20 \mathrm{DAS})\end{array}$ & 33.8 & 6.6 & 19.5 & 9.9 & 32.5 & 14.59 & 24.1 & 7.16 \\
\hline 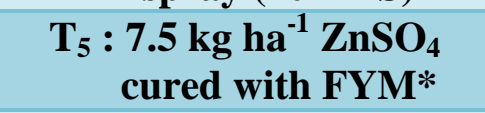 & 36.5 & 6.6 & 21.4 & 10.5 & 32.5 & 15.69 & 24.5 & 7.39 \\
\hline $\begin{array}{l}\mathrm{T}_{6}: \mathrm{T}_{5}+0.5 \% \mathrm{ZnSO}_{4} \\
\quad \text { foliar spray }(20 \mathrm{DAS})\end{array}$ & 45.1 & 7.6 & 26.2 & 12.7 & 34.5 & 19.47 & 29.2 & 8.65 \\
\hline $\begin{array}{c}\mathrm{T}_{7}: \mathrm{T}_{5}+1 \% \mathrm{ZnSO}_{4} \text { foliar } \\
\text { spray }(20 \mathrm{DAS})\end{array}$ & 41.7 & 6.6 & 23.3 & 11.9 & 33.3 & 17.95 & 27.6 & 8.03 \\
\hline $\begin{array}{r}\mathrm{T}_{8}: 10 \mathrm{~kg} \mathrm{ha}^{-1} \mathrm{ZnSO}_{4} \\
\text { cured with } \mathrm{FYM}^{*}\end{array}$ & 37.7 & 6.9 & 21.8 & 10.7 & 32.0 & 15.88 & 25.3 & 7.64 \\
\hline $\begin{array}{l}\mathrm{T}_{9}: \mathrm{T}_{8}+0.5 \% \mathrm{ZnSO}_{4} \\
\quad \text { foliar spray }(20 \mathrm{DAS})\end{array}$ & 44.3 & 7.4 & 25.6 & 12.5 & 33.9 & 18.83 & 29.1 & 8.43 \\
\hline $\begin{array}{l}\mathrm{T}_{10}: \mathrm{T}_{8}+1 \% \mathrm{ZnSO}_{4} \\
\text { foliar spray }(20 \mathrm{DAS})\end{array}$ & 38.6 & 6.7 & 23.1 & 11.8 & 33.1 & 17.32 & 27.4 & 8.14 \\
\hline S.Em+/- & 0.91 & 0.19 & 0.43 & 0.16 & 0.37 & 0.36 & 0.37 & 0.42 \\
\hline CD 5\% & 2.69 & 0.56 & 2.18 & 0.47 & 1.09 & 1.08 & 1.10 & 1.34 \\
\hline
\end{tabular}

\section{Results and Discussion}

The results obtained from the present investigation as well as relevant discussion have been summarized under following heads:

The highest plant height, number of branches per plant and dry matter per plant was recorded in $\mathrm{T}_{6}$ which received $7.5 \mathrm{~kg} \mathrm{ha}^{-1}$ $\mathrm{ZnSO}_{4}$ cured with FYM and $0.5 \% \mathrm{ZnSO}_{4}$ foliar spray 20 DAS. Plant height $45.1 \mathrm{~cm}$, number of branch per plant 7.6 and dry matter per plant 26.2 and lowest plant height 23.7 $\mathrm{cm}$, number of branches per plant 5.6 and dry matter per plant $13.7 \mathrm{gm}$ was recorded in control. This might be due to application of zinc sulphate was mainly because, zinc being an essential constituent of several enzymes and also involved in nitrogen metabolism, cellular proteins and nucleic acid synthesis and encouraged the meristemetic activities of greengram and increased uptake of all the nutrients which in turn helped in better plant growth and dry matter production. The results are in accordance with the findings of Ram $e t$ al., (2008) and Yadav et al., (2012).

Grain weight per plant and number of pods per plant of greengram differed significantly 
with zinc levels. The treatment, $\mathrm{T}_{6}$ which received $7.5 \mathrm{~kg} \mathrm{ha}^{-1} \mathrm{ZnSO}_{4}$ cured with FYM and $0.5 \% \mathrm{ZnSO}_{4}$ foliar spray 20 days after sowing recorded significantly higher number of grain weight per plant (12.7 g) and number of pods per plan (29.2). Which might be due to increase in photosynthetic rate and there by increased dry matter production and translocation from source to sink. Sharma and Abraham (2010) reported that application of $15 \mathrm{~kg}$ zinc sulphate per ha to blackgram recorded higher haulm yield over the control.

Sasode (2006) noticed higher haulm yield (33.26 q/ha) compared to other treatments with $5 \mathrm{~kg} \mathrm{ha}^{-1}$ zinc sulphate application in blackgram. Similar findings are reported by Shanti et al., (2008), Babu et al., (2012) and Usman et al., (2014).

The highest seed yield(8.65 q /ha), haulm yield $(19.47 \mathrm{q} / \mathrm{ha})$ and test weight $(34.5 \mathrm{~g})$ was recorded in treatment $\mathrm{T}_{6}$ that received 7.5 $\mathrm{kg} \mathrm{ha}^{-1} \mathrm{ZnSO}_{4}$ cured with FYM and $0.5 \%$ $\mathrm{ZnSO}_{4}$ foliar spray 20 days after sowing and as compared to all other treatment and control (6.57 q/ha) may be due to more photosynthetic activity, uptake of nutrients, photosynthate translocation from source to sink and higher reproductive activity. Similar results were obtained by Hugar and Kurdikeri (2000).

Further, Sharma and Abraham (2010) reported that application of $15 \mathrm{~kg}$ zinc sulphate per ha to blackgram recorded higher number of pods per plant. Valenciano et al., (2011) reported higher number of pods per plant and 1000-seed weight in chickpea.

Application of zinc at $15 \mathrm{~kg} \mathrm{ha}^{-1}$ to recorded higher number of pods per plant (33.37) and 1000 -seed weight (28.79 g) over control as reported by Ram et al., (2008). Similarly, Khourgami and Fard (2012) reported that zinc spraying on greengram recorded higher 1000- seed weight (37.9 g).

The results of present investigation are also in agreement with Usman et al., (2014) and Ram et al., (2013).

\section{References}

Ali, M. and Gupta. S., 2012, Carring capacity of Indian agriculture: pulse crops. Current sci., 102(2):874-881

Ram, S. and Katriyar, T. S., 2013, Effect of sulphur and zinc on the seed yield and protein content of summer mungbean under arid climate, Indian J. Agric. Sci., 4(3) : 563-566.

Usman, M., Tahir, M. and Majeed, M. A., 2014, Effect of zinc sulphate as soil application and seed treatment on green gram (Vigna radiata L.). Pak. J. Life Soc. Sci., 12(2): 87- 91.

Khourgami, A. and Fard, S. R., 2012, The effect of zinc spraying and plant density on yield and yield components of greengram (Vigna radiata). Ann. Bio. Res., 3(8): 4172-4178.

Ram, V., Ali, M., Misra, S. K. and Upadhyay, R. M., 2008, Studies on sulphur, zinc and biofertilizers on yield, yield attributes and nutrient content at different growth stages in mungbean (Vigna radiata). J. Food Legumes, 21(4): 240-242.

Valenciano, J. B., Boto, J. A. and Marcelo, V., 2011, Chickpea (Cicer arietinum L.) response to zinc, boron and molybdenum application under field conditions. New Zealand J. Crop Horti. Sci., 39(4): 217-229.

Sharma, V. and Abraham, T., 2010, Response of blackgram (Vigna mungo) to nitrogen, zinc and farm yard manure. Legume Res., 33(4): 295-298.

Hugar, A. B. and Kurdikeri, M. B., 2000, Effect of application methods and levels of zinc and molybdenum on field 
performance and seed yield in soybean. Karnataka J. Agric. Sci., 13: 439-441.

Babu, P. N. S., Koppalkar, B. G., Desai, B. K., Nagalikar, V. P. and Katti, P., 2012, Yield, yield components and economics of pigeonpea cultivation as influenced by organic manures and graded levels of zinc sulphate. Karnataka J. Agri. Sci., 25(4): 527-530.

Shanti, M., Babu, B. P., Prasad, R. and Minhas, P. S., 2008, Effect of zinc on blackgram in rice blackgram cropping systems of coastal saline soils. Legume
Res., 31(2): 79-86.

Sasode, D. S., 2006, Effect of fertility levels and sulphur sources on yield and seed quality of mungean (Vigna radiata) and fertility of alluvial soil. Legume Res., 29(3): 221-224.

Yadav, L. R., Choudhary, P., Santosh, O. P. and Choudhary, M., 2012, Effect of phosphorous and zinc on yield and economics of mothbean under semi-arid conditions. J. Food Legumes, 25(4): 361-363.

\section{How to cite this article:}

Prashantkumar and B. M. Radder. 2020. Effect of Zinc Sulphate on Yield and Yield Attributes of Green Gram (Vigna Radiata). Int.J.Curr.Microbiol.App.Sci. 9(02): 2209-2213. doi: https://doi.org/10.20546/ijcmas.2020.902.249 